\title{
PENGARUH PERKIRAAN BIAYA PRODUKSI \\ DAN LABA YANG DIINGINKAN \\ TERHADAP HARGA JUAL \\ (STUDI KASUS PADA USAHA BARU JAYA TEKNIK \\ PERIODE 2015-2017)
}

\author{
Tismona Avelia, Renil Septiano \\ Akuntansi, Sekolah Tinggi Ilmu Ekonomi “KBP” Padang \\ Email: trismonaavelia@gmail.com \\ renil.septiano@akbpstie.ac.id
}

\begin{abstract}
Implementation of production cost calculation as a step to set the selling price on the product and get the desired profit in a company is very important for the company, because the application of cost calculations used in memproduksi a product is the first step for us to gain profit and can maintain our company. This research was conducted on New Tech Jaya Engineering which address at Jl. Raya warranty no.35 kel. The water is dashing. Koto tangah padang city. Data obtained through site-to-site surveys and direct interviews with new business owners of technical trials are concerned with the issues discussed and the documents as supporting evidence. The result of this research shows that production cost (X1) t arithmetic <t table is 53,626>1,69092 with significance 0,000 $<0,05$ then $\mathrm{Hl}$ is accepted, there is significant influence between variable of production cost $(X 1)$ to selling price $(Y)$. For the desired profit variable $(X 2)$ the value of $t$ count $>t$ table is 3.097> 1.69092 with significance of $0.004<0.05$ then $H_{2}$ is accepted, it means there is a significant influence between the desired profit $(X 2)$ on selling haga $(Y)$.
\end{abstract}

Keywords: Production cost, desired profit, selling price

\section{PENDAHULUAN}

Pada era modern saat sekarang melihat adanya kemajuan teknologi yang semakin hari semakin canggih dan persaingan di dunia bisnis yang semakin ketat terutama pemasaran produk, memberikan tuntutan yang semakin besar persaingannya bagi perusahaan. Agar mereka mampu mempertahankan dan lebih mengembangkan usaha yang telah ada. Perencanaan penjualan adalah ramalan unit dan nilai uang penjualan suatu perusahaan untuk periode dimasa yang akan datang yang di dasarkan pada tren penjualan terakhir (Brigham, eugene F, 2001) Berbicara dengan membentuknya sebuah usaha tentu banyak hal yang harus dipertimbangkan, baik itu biaya-biaya yang akan kita gunakan, penetapan harga jual yang tepat beserta laba yang akan kita peroleh nantinya, semua itu akan mencangkup di dalam usaha yang akan kita buat. Namun kebanyakan perusahaanperusahaan kecil yang bergerak dibidang manufaktur masih kurang tepat atau bahkan belum menerapkan pencatatan ataupun perhitungan biaya produksi. 
Padahal perhitungan biaya produksi ini akan membentuk harga pokok produksi atau cost of production dan ini merupakanlangkah awal yang harus ditempuh oleh setiap unit usaha, selain meningkatkan kualitas produk untuk mengembangkan dan mempertahankan unit usahanya ditengah persaingan pasar perhitungan biaya produksi mampu menjadi dasar untuk penentuan harga jual.

Menurut teori (Mowen, 2006) perhitungan biaya produksi adalah salah satu kegiatan yang dilakukan oleh perusahaan dengan akurat, tepat, dan jelas juga sangat penting dalam menentukan harga pokok penjualan.Menurut (Mulyadi, 2005) penetapan Harga Jual pada dasarnya harus dapat menutupi biaya penuh ditambah dengan laba yang wajar, harga jual sama dengan biaya produksi ditambah mark-up Secara simultan antara perkiraan biaya produksi, dan laba yang diinginkan terhadap harga jual mempunyai pengaruh yang bersifat positif sebesar 34,9\% sisanya dipengaruhi oleh faktor eksternal seperti elastisitas permintaan (Achmad Slamet, 2002)menunjukan bahwa secara parsial perkiraan biaya produksi berpengaruh secara positif terhadap harga jual, artinya setiap kenaikan pada perkiraan biaya produksi terhadap harga jual akan diikuti oleh kenaikan harga jual dan penurunaan perkiraan biaya poduksi akan diikuti oleh penurunan harga jual. Sedangkan pengaruh laba yang diinginkan terhadap harga jual berdasarkan persamaan regresi bersifat positif. Artinya bahwa kenaikan laba yang diinginkan akan diikuti oleh kenaikan harga jual dan penurunan laba yang diinginkan akan diikuti oleh penurunan harga jual.

\section{TINJAUAN PUSTAKA \\ BiayaProduksi}

Menurut (Carter-Usry, 2005) Teori Biaya Produksi adalah jumlah dari tiga unsur biaya yaitu biaya produksi langsung, biaya tenaga kerja langsung, dan biaya overhead pabrik. Biaya produksi langsung dan biaya tenaga kerja langsung dapat digolongkan ke dalam golongan utama (primer cost). Biaya tenaga kerja langsung dan biaya overhead pabrik dapat digabung ke dalam golongan konversi (Conversion Cost), yang mencerminkan biaya pengubahan bahan langsung menjadi barang jadi.

\section{Laba yang dinginkan}

Menurut (Kuswadi, 2006) Teori Laba adalah pendapatan dan hasil penjualan dikurangi biaya-biaya pengadaan dan pemasaran. Dan Menurut(Ruky, 2002) Teori Laba adalah sebagian dari hasil penjualan barang atau jasa yang dihasilkan perusahaan setelah dikurangi seluruh biaya operasinya termasuk biaya produksi (pembelian bahan, upah, gaji, dan lain-lain) biaya penjualan dan biaya operasi langsung lainnya seperti sewa-sewa, asuransi, pajak dan lain sebagainnya.

\section{Harga Jual}

Menurut (Mulyadi, 2005) Teori Harga Jual adalah pada dasarnya harus dapat menutupi biaya penuh ditambah dengan laba yang wajar, harga jual sama dengan biaya produksi ditambah mark-up. Menurut (Supriyono, 2002) mengemukakan bahwa harga jumlah adalah jumlah moneter yang dibebankan oleh suatu unit usaha kepada pembeli atau pelanggan atas barang atau jasa yang 
dijual atau diserahkan.

\section{Hipotesis}

$\mathrm{H} 1 \quad=$ Ada pengaruh positif biaya produksi terhadap harga jual

$\mathrm{H} 2$ = Ada pengaruh positif laba terhadap harga jual

$\mathrm{H} 3$ = Ada pengaruh positif biaya produksi dan laba yang diinginkan terhadap harga jual

\section{Kerangka Konseptual}

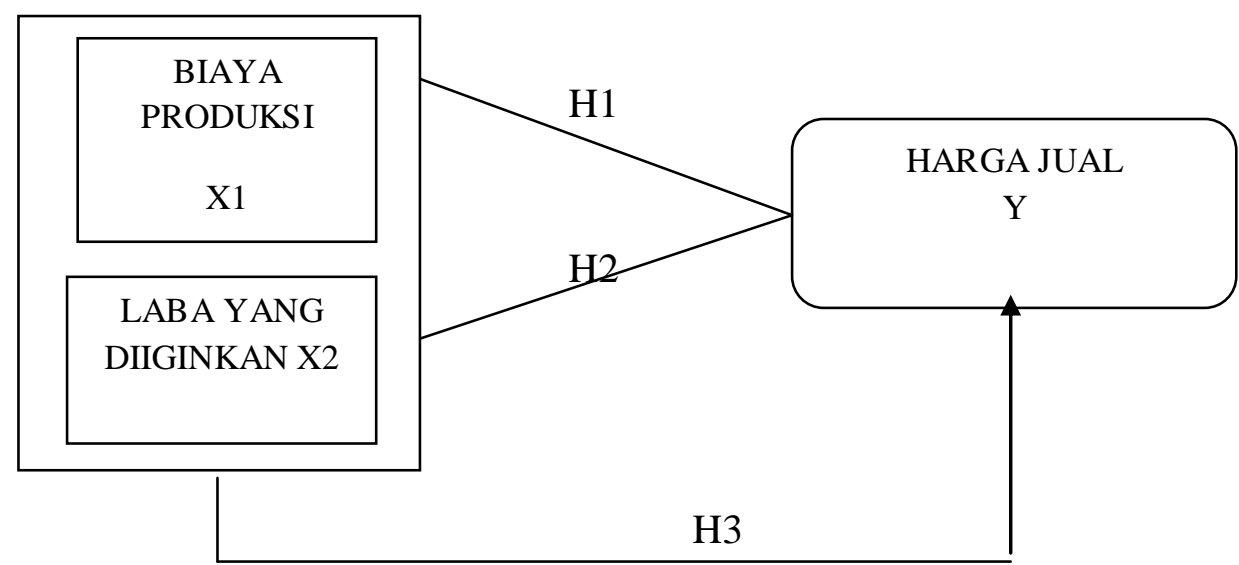

\section{METODE PENELITIAN}

\section{Jenis Penelitian}

Jenis penelitian ini adalah penelitian kuantitatif. Penelitian kuantitatif dapat diartikan sebagai metode penelitian yang berlandaskan pada filsafat positivisme, digunakan untuk meneliti pada populasi atau sampel tertentu. Teknik pengambilan sampel pada umumnya dilakukan secara random, pengumpulan data menggunakan instrumen penelitian, analisis data bersifat kuantitatif/statistik dengan tujuan untuk menguji hipotesis yang telah ditetapkan (Sugiyono, 2012)

\section{Variabel Penelitian}

Menurut (Sugiyono, 2013)variabel adalah segala sesuatu yang berbentuk apa saja yang ditetapkan oleh peneliti untuk dipelajari sehingga diperoleh informasi tentang hal tersebut, kemudian ditarik kesimpulannya.

1. Variabel bebas (independent variabel)

2. Variabel terkat (dependen variabel)

\section{Defenisi Operasional}

Defenisi operasional variabel menurut (sugiyono, 2013) merupakan suatu defenisi yang diberikan kepada suatu variabel dengan memberi arti atau menspesifikkan kegiatan atau membenarkan suatu operasional yang diperlukan untuk mengukur variabel tersebut

\section{Sumber data}


Yaitu berupa data Primer, data yang diperoleh langsung dari objek yang akan diteliti (tidak melaluiperantara) berupa hasil wawancara langsung dengan pemilik usaha baru jaya teknik pembuatan tralis besi dan didukung data yang dikelompokkan oleh pengusaha tralis besi berupa pembelian bahan baku untuk lebih mampu memperkuat data.

\section{Tenik analisis data}

Analisis regresi linier berganda

Menurut Sujarweni (2016), regresi berganda bertujuan untuk menguji pengaruh antara variabel bebas (independent) dengan variabel (dependent). Regresi berganda memiliki satu variabel dependen dan lebih dari satu variabel independen.

Model persamaan analisis berganda adalah sebagai berikut:

$\mathrm{Y}=\alpha+\beta 1$ biaya produksi $+\beta 2$ laba yang diinginkan $+\mathrm{e}$

Dimana :

$\mathrm{Y}=$ Harga jual $\quad \beta=$ Slope atau Koefisien Regresi

$\alpha=$ Konstanta $\quad \mathrm{e}=$ Error

\section{Uji Asumsi Klasik}

Menurut (Ghozali, 2014)pengujian asumsi klasik atas data penelitian, dilakukan dengan menggunakan empat model pengujian yaitu:

Uji Normalitas

Uji normalitas menurut (Ghozali, 2014) bertujuan untuk menguji apakah dalam model regresi variabel pengganggu atau residual memiliki distribusi normal. Seperti uji $t$ dan uji $F$ mengasumsikan bahwa nilai residual mengikuti distribusi normal. Kalau asumsi ini dilanggar maka uji statistik menjadi tidak valid untuk jumlah sampel kecil.

\section{Uji Multikolinieritas}

Uji multikolinearitas menurut (Ghozali, 2014) bertujuan untuk menguji apakah model regresi ditemukan adanya korelasi antar variabelbebas (independen). Model regresi yang baik seharusnya tidak terjadi korelasi diantara variabel independen. Jika variabel independen saling berkorelasi, maka variabelvariabel ini tidak ortogonal. Variabel ortogonal adalah variabel independen sama dengan nol. Untuk mendeteksi ada atau tidaknya multikolonieritas di dalam model regresi. Untuk mendeteksi ada tidaknya multikolonieritas di dalam model regresi dapat dilihat dari:

1) Nilai tolerance

2) Variance Inflation Factor (VIF)

\section{Uji Autokorelasi}

Autokolerasi merupakan pelonggaran asumsi klasik yang menyatakan bahwa dalam pengamatan-pengamatan yang berbeda tidak terdapat kolerasi antar error term. Auto kolerasisering disebut dengan kolerasi serial (serial correlation) terjadi kebanyakan pada serangkaian data runtut waktu (time series). Model linear klasik mengasumsikan bahwa autokolerasi demikian tidak terdapat/memiliki kesalahan pengganggu. Jika terjadi masalah autokorelasi maka nilai probabilitas di atas nilai signifikansi yaitu alpha sama dengan 0,05.

\section{Uji heterokedastisitas}


Menurut (Ghozali, 2014) bertujuan untuk menguji apakah dalam model regresi terjadi ketidaksamaan varians dari residual satu pengamatan kepengamatan yang lain. Jika varians dari residual satu pengamatan ke pengamatan lain tetap, maka disebut Homoskedastisitas dan jika berbeda disebut Heterokedastisitas. Model regresi yang baik adalah yang Homokedastisitas atau tidak terjadi Heterokedastisitas. Salah satu cara untuk mendeteksi adanya heteroskedastisitas adalah dengan melihat grafik plot antara nilai prediksi variabel independen (ZPRED) dengan residualnya (SRESID). Deteksi ada tidaknya heteroskedastisitas dapat dilakukan dengan melihat ada tidaknya pola tertentu pada grafik scatterplot antara SRESID dan ZPRED dimana sumbu Y adalah Y yang telah diprediksi, dan sumbu $\mathrm{X}$ adalah residual (Y prediksi -Y sesungguhnya) yang telah di-studentized

\section{Uji Hipotesis}

\section{Goodness Of Fit (F Statistik atau F test)}

Menurut (Ghozali, 2014) Uji Statistik F pada dasarnya menunjukkan apakah semua variabel independen atau variabel bebas yang dimasukkan dalam model mempunyai pengaruh secara bersama-sama terhadap variable dependen atau variabel terikat

\section{T-Test (Uji Statistik)}

Menurut (Ghozali, 2014) Uji beda t-test digunakan untuk menguji seberapa jauh pengaruh variabel independen yang digunakan dalam penelitian ini secara individual dalam menerangkan variabel dependen secara parsial.

\section{Koefisien Determinasi $\left(R^{2}\right)$}

Menurut (Ghozali, 2014), Koefisien determinasi $\left(\mathrm{R}^{2}\right)$ merupakan alat yang digunakan untuk mengukur seberapa jauh pengaruh semua variabel independen mempengaruhi variabel dependen. Nilai koefisien determinasi adalah 0 atau 1. Nilai $\mathrm{R}^{2}$ yang kecil berarti kemampuan variabel-variabel independen dalam menjelaskan variasi variabel dependen amat terbatas. Dan sebaliknya nilai yang mendekati 1 berarti variabel-variabel independen memberikan hampir semua informasi yang dibutuhkan untuk memprediksi variabel-variabel dependen.

\section{HASIL DAN PEMBAHASAN}

Hasil Regresi Linear Berganda

Coefficients $^{\mathrm{a}}$

\begin{tabular}{|c|c|c|c|c|c|}
\hline \multirow[b]{2}{*}{ Model } & \multicolumn{2}{|c|}{$\begin{array}{c}\text { Unstandardized } \\
\text { Coefficients }\end{array}$} & \multirow{2}{*}{$\begin{array}{l}\text { Standardized } \\
\text { Coefficients } \\
\text { Beta }\end{array}$} & \multirow[b]{2}{*}{$\mathrm{T}$} & \multirow[b]{2}{*}{ Sig. } \\
\hline & B & Std. Error & & & \\
\hline 1 (Constant) & 3062741,647 & 386197,362 & & 7,931 & ,000 \\
\hline Biaya produksi & 1,032 & ,019 & ,985 & 53,626 & ,000 \\
\hline $\begin{array}{l}\text { Laba yang di } \\
\text { inginkan }\end{array}$ & ,013 & ,004 & ,057 & 3,097 & ,004 \\
\hline
\end{tabular}

a. Dependent Variable: Harga jual

Sumber : Hasil Pengolahan Data Spss, 2017 
Berdasarkan Tabel 4.8 Maka ringkasan hasil pengujian dapat diformulasikanpersamaan regresinya sebagai berikut :

$Y=3062741,647+1,032 X_{1}+, 013 X_{2}+e$

Dimana:

$\mathrm{Y}=$ Harga jual

$\mathrm{X} 1=$ biaya produksi

$\mathrm{X} 2$ = laba yang diinginkan

e $\quad=$ Error

a. Dari persamaan tersebut dapat dilihat bahwa, konstanta $=3062741,647$ ini menunjukkan bahwa tanpa variabel bebas (biaya produksi dan laba yang diinginkan) maka terjadi peningkatan harga jual yaitu sebesar nilai konstanta yang dihasilkan yaitu 3062741,647

b. Koefisien Regresi X1 = 1,032, Artinya setiap peningkatan variabel biaya produksi sebesar $1 \%$ akan menaikkanharga jual sebesar1,032dengan menganggap variabel lain dalam model konstan.

c. Koefisien Regresi X2 =0,013, Artinya setiap peningkatan variabel laba yang di inginkan sebesar $1 \%$ akan meningkatkan variabel harga jual sebesar0,013 dengan menganggap variabel lain dalam model konstan.

\section{Uji Hipotesis}

\section{Uji F}

Untuk menguji pengaruh variabel bebas secara bersama-sama diuji dengan menggunakan uji F. Hasil perhitungan regresi secara simultan diperoleh sebagai berikut:

\section{Uji F}

ANOVA $^{\mathrm{a}}$

\begin{tabular}{|c|c|c|c|c|c|}
\hline Model & Sum of Squares & df & Mean Square & $\mathrm{F}$ & Sig. \\
\hline 1 Regression & 724689454076999,200 & 2 & 362344727038499,600 & 1495,858 &, $000^{\mathrm{b}}$ \\
\hline Residual & 7993657799950,640 & 33 & 242232054543,959 & & \\
\hline Total & 732683111876949,900 & 35 & & & \\
\hline
\end{tabular}

a. Dependent Variable: Harga jual

b. Predictors: (Constant), Laba yang di inginkan, Biaya produksi

Sumber : Hasil Pengolahan Data SPSS, 2017

Berdasarkan dari hasil pengujian pada tabel 4.9 dapat dilihat pada nilai signifikansi hipotesis secara simultan adalah 0,000 , hal ini menunjukkan bahwa nilai signifikansi lebih kecil dari 0,05 maka berarti terdapat pengaruh yang signifikansi secara bersama-sama antara biaya produksi(X1), laba yang di inginkan (X2) dan harga jual(Y). Tingkat signifikansi yang digunakan dalam pengujian adalah $\alpha=0,05$, derajat kebebasan ialah df1 ( Jumlah variabel -1$)=3$ $-1=2$ dan df 2 (jumlah sampel - jumlah variabel $)=36-2=34$.

Setelah melihat tabel $F$, maka hasil yang diperoleh untuk $f$ tabel adalah sebesar 2,89. Jika dibandingkan nilai antara $f$ hitung dengan $\mathrm{f}$ tabel maka $\mathrm{f}$ hitung $>$ f tabel yaitu 1495,858>2,89. Jadi dapat disimpulkan bahwa perkiraan biaya produksi dan laba yang diinginkan (simultan) memiliki pengaruh yang signifikan terhadap harga jual. 


\section{Hasil Uji T-Test (Uji Statistik)}

Uji T-Test

Coefficients $^{\mathrm{a}}$

\begin{tabular}{|l|r|r|}
\hline Model & \multicolumn{1}{|c|}{ T } & \multicolumn{1}{l|}{ Sig. } \\
\hline (Constant) & 7,931 &, 000 \\
Biaya produksi & 53,626 &, 000 \\
Laba yang di inginkan & 3,097 &, 004 \\
\hline
\end{tabular}

a. Dependent Variable: Harga jual

Sumber : Data Olahan Dengan Spss, 2017

Dapat dilihat pada tabel 4.10 bahwa Dengan tingkat signifikasi menggunakan $\alpha=0,05$ dan derajat kebebasan $(\mathrm{df})=$ jumlah sampel $-2=36-2$ $=34$. Dengan merujuk pada tabel $\mathrm{t}$, maka diperoleh hasil $\mathrm{t}$ tabel yaitu sebesar 1,69092

Dari tabel 4.10 diketahui untuk biaya produksi (X1) $t$ hitung $<\mathrm{t}$ tabel yaitu 53,626 >1,69092 dengan signifikansi 0,000 < 0,05 maka H1 diterima, berarti terdapat pengaruh yang signifikan antara variabel biaya roduksi (X1) terhadap harga jual (Y).

Untuk variabel laba yang diinginkan (X2) nilai thitung > t tabel yaitu 3,097 > 1,69092 dengan signifikansi sebesar 0,004<0,05 maka H2 diterima, berarti terdapat pengaruh yang signifikan antara laba yang diinginkan (X2) terhadap haga jual (Y).

Koefisien Determinasi (R2)

\section{Uji Determinasi (R2)}

Model Summary ${ }^{\mathrm{b}}$

\begin{tabular}{|c|c|c|c|c|}
\hline Model & R & R Square & Adjusted R Square & Std. Error of the Estimate \\
\hline 1 &, $995^{\mathrm{a}}$ &, 989 &, 988 & 492170,758 \\
\hline
\end{tabular}

a. Predictors: (Constant), Laba yang di inginkan, Biaya produksi

b. Dependent Variable: Harga jual

Sumber : Hasil Pengolahan Data SPSS, 2017

Hasil perhitungan regresi dapat diketahui bahwa koefisien determinasi R2) yang diperoleh sebesar 0,988. Hal ini berarti 98,8\%perkiraan biaya produksi dan laba yang diinginkan dapat dipengaruhi oleh harga jual, sedangkan sisanya sebesar $1,2 \%$ diterangkan oleh variabel lain yang tidak diajukan dalam penelitian ini.

\section{Pembahasan}

\section{Pengaruh Biaya Produksi Terhadap Harga Jual}

Berdasarkan hipotesis pertama telah di asumsikan bahwa biaya produksi berpengaruh positif dan sinifikan terhadap harga jual pada usaha baru jaya teknik.

Dari hasil pengolahan data di hasilkan nilai koefisien regresi untuk variabel laba yang diinginkan53,626>1,69092 dengan signifikansi 0,000 $<0,05$ yang berarti bahwa laba yang diinginkan mempunyai pengaruh positif dan signifikan terhadap harga jual. Dengan demikian dapat disimpulkan hipotesis pertama diterima.

Penelitian ini konsisten dengan hasil penelitian yang dilakukan achmad slamet (2002) bahwa secara statistik biaya produksi berpengaruh signifikan 
terhadap harga jual. Hal ini berarti bahwa jika biaya produksi menurun maka harga jual yang akan di tetapkan akan menurun juga karna kurangnya produksi atau kurang lancarnya produksi.

\section{Pengaruh laba yang diinginkan terhadap harga jual}

Berdasarkan hipotesis kedua telah di asumsikan bahwa laba yang diinginkan juga berpengaruh dan signifikan terhadap harga jual.Dari hasil pengolahan data dapat di hasilkan nilai koefisienregresi biaya produksisebesar 3,097>1,69092 dengan signifikansi sebesar 0,004<0,05 yang berarti bahwa laba yang diinginkan mempunyai pengaruh positif dan signifikanterhadap harga jual.Dengan demikian dapat disimpulkan hipotesis kedua di terima.

Penelitian ini konsisten dengan penelitian yang dilakukan oleh andri eka permatasari (2013) Bahwa secara statistik laba yang diinginkan berpengaruh signifikan terhadap harga jual. Hal ini berarti bahwa dengan laba yang diinginkan naik, maka harga jual dapat memberikan hasil yang baik juga atau harga jual naik.

\section{Pengaruh perkiraan biaya produksi dan laba yang diinginkan terhadap harga jual}

Hasil peneltian menunjukkan bahwa perkiraan biaya produksi dan laba yang diinginkan secara bersama-sama (simultan) memiliki pengaruh yang signifikan terhadap harga jual.

Dari hasil pengolahan data di hasilkan bahwa perbandingan antara nilai $\mathrm{f}$ hitung dengan $\mathrm{f}$ tabel maka $\mathrm{f}$ hitung $>\mathrm{f}$ tabel yaitu 1495,858> 2,89. Jadi dapat disimpulkan bahwa perkiraan biaya produksi dan laba yang diinginkan secara bersam-sama memiliki pengaruh yang signifikan terhadap harga jual.

Penelitian ini konsisten dengan penelitian (S Achmad Slamet, 2002)bahwa perkiraan biaya produksi dan laba yang diinginkan berpengaruh signifikan terhadap harga jual..Hasil penelitian ini sejalan dengan penelitian (Sutriyani, 2013)Bahwa biaya produksi berpengaruh positif dan signifikan terhadap harga jual. Hal ini berarti bahwa semakin besar biaya produksi yang diterapkan pada penentuan harga jual maka akansemakin besar pula harga jual yang akan ditetapkan begitu juga dengan laba semakin besar laba yang diharapkan maka penetapan harga jual harus semakin besar juga.

\section{SIMPULAN}

Dari analisis variabel biaya produksi dan laba yang diinginkan yang telah dilakukan maka dapat disimpulkan bahawa Biaya produksi (X1) t hitung $<\mathrm{t}$ tabelyaitu53,626 >1,69092 dengan signifikansi 0,000 < 0,05 maka H1 diterima, berarti terdapat pengaruh yang signifikan antara variabel biaya roduksi (X1) terhadap harga jual (Y). Untuk variabel laba yang diinginkan (X2) nilai thitung $>\mathrm{t}$ tabelyaitu3,097 >1,69092 dengan signifikansi sebesar 0,004 $<0,05$ maka $\mathbf{H 2}$ diterima, berarti terdapat pengaruh yang signifikan antara laba yang diinginkan (X2) terhadap haga jual (Y).

\section{UCAPAN TERIMA KASIH}

Peneliti sangat berterima kasih kepada:

1. Ketua Stie KBP Padang Bapak Febryandhie Ananda SE, MSi.

2. Ketua Program Studi Dewi Zulvia SE, MM. 
3. Dosen Pembimbing Renil Septiano SE, MM

4. Pembimbing Akademik Lisa Amelia Herman SE, Msi.

5. Usaha baru jaya teknik yang membantu pelaksanaan penelitian dan karya tulis ilmiah.

\section{DAFTAR PUSTAKA}

Achmad Slamet, S. (2002). Diinginkan, Laba Yang Jual, Harga Masalah, Latar Belakang, 11(2).

Brigham, eugene F, dan joel f. houston. (2001). manajemen keuangan edisi 8,erlangga. jakarta.

Carter-Usry. (2005). Akuntansi Biaya , Anggaran dan Biaya Standar. Edisi 13, penerbit BPEF. Jakarta.

Ghazali, I. (2012). pengertian normalitas, multikoloneritas,Heteroskedasitas dan Uji Autokorelasi.

Ghozali. (2014). Aplikasi analisis multivariate dengan program IBM SPSS 20. Semarang: Universitas Diponegoro.

Kuswadi. (2006). Memahami Rasio Keuangan. Jakarta.

Mowen, H. (2006). akuntansi manajemen,perhituang biaya,edisi empat, salemba empat. Jakarta.

Mulyadi. (2005). Akuntanasi Biaya, Edisi 5. Yogyakarta.

Ruky, A. S. (2002). Sukses sebagai manajer profesional tanpa gelar: pt.gramedia. Jakarta.

Sugiyono. (2012). Metode penelitian kuantitatif,kualitatif dan $R \& D$. Bandung.

Sujarweni, V. W. (2016). Kupas Tuntas Penelitian Akuntansi dengan SPSS. Yogyakarta: Pustaka Baru Press.

Supriyono. (2002). Akuntansi Manajemen, proses pengendalian manajemen. Yogyakarta.

Sutriyani, Y. (2013). Pngaruh harga pokok produksi terhadap harga jual pada PT.Profab Indonesia. 